\title{
WHAT'S WRONG WITH THE ASSESSMENT OF NUTRITIONAL DEPRIVATION? A TALE OF RURAL INDIA
}

\section{K ANTONY AKHIL}

Research Scholar, Department of Economics, Central University of Kerala, Kasaragod, India

\begin{abstract}
The aim of the paper was to quantify the proportion of undernourished households in rural India, without relying on any particular calorie cutoff point. For that mean, RDA has been estimated at the household level, after adjusting for age and gender distribution of the sedentary household members. The two NSS rounds that pertain to the years 2004-05 and 2011-12 are used here. An investigation of the determinants of calorie deprivation leads us to the finding that poor households, ST and OBC households, causal labour in agriculture, self-employed in non-agriculture and Christians have the highest probability of being calorie deprived. Among the backward states, higher incidence of nutritional deprivation persists among Assam, Madhya Pradesh, Orissa and West Bengal. The legacy of higher calorie deprivation in leading states is not a cause of worry. Lower the nutritional intake, higher will be the absorption level in Southern and Western states due to their improved ways of living.

KEYWORDS: Deprivation, Logit, Nutrition \& Poverty
\end{abstract}

Received: Jul 05, 2017; Accepted: Jul 26, 2017; Published: Aug 04, 2017; Paper Id.: IJECRAUG201712

\section{INTRODUCTION}

With the celebrated reduction of rural poverty, a commensurate fall in the level of undernutrition may not come about in reality. The growing divergence between hunger and poverty and the public policy inertia with regard to undernutrition (Basu and Das, 2014; Rao, 2016) has contributed to a number of studies in the area. However, none of them are satisfactory in that it often revolves around arbitrary calorie norms and its likely correlates.

As is well established, undernutrition stems from imbalanced diets and from the perceived deficiencies of macro and micro nutrients. Since low socio-economic status of a household is inextricably linked to undernutrition, an understanding of the level and proximate causes of undernutrition forms the bedrock of this paper. The recent undernutrition levels in rural states have been improved, but the temporal improvement is far from satisfactory. For example, the chronic energy deficiency of adults (proportion of adults with body mass index less than 18.5) which was at 40 per cent in 2000-01, is now fell to 35 per cent in 2011-12 (Radhakrishna, 2005; Dreze, 2007, NNMB, 2012). With the significant strides in poverty reduction, a modest improvement was only discernible in case of the outcome indictor, which was reflected by the body mass index of the population. Hence, it is necessary to look at the input indicator that accommodates the nutritional intake of the household; the deficiency of it surmounts to the nutritional deprivation.

There is a consensus among the studies that poverty ratios in rural areas seem to have declined. The divergence between hunger and poverty suggests that there will be some problems either with the measurement of 
poverty or with the measurement of undernutrition or with both the measures. To get around the issues relating to the measurement of undernutrition, we have estimated the 'true' calorie requirements without relying on any calorie thresholds and then arrived at the nutritional deprivation of households. Our estimation has largely been based on the age and gender adjusted requirements of nutrients by the rural population. Such an innovative approach is followed on account of the fact that food and nutritional intake varies with the age and gender differences due to the differences in activity status, metabolism rates, and other physiological factors. Apart from this, there is lingering and unequal distribution of food to the old and girl child within the family.

The monthly per capita consumption expenditure is adopted here as a proxy for the economic status of the household. The nutritional status of the household is also conditioned by household types, occupation categories, religious factors, and among others. Two variables which seem to be pertinent in the study are households having dependent members and households possessing no ration card. An increase in the dependent population would make at risk overall household nutritional security. Furthermore, the inclusion of the latter variable may point to the errors in pinning down the true beneficiaries of targeted public distribution system. The paper apart from the introduction has three sections. The first section begins with the rural transformation that is currently underway in India. The second section deals with the computation of RDA and the distance from average nutritional requirements. The third section looks for the correlates of nutritional deprivation in rural India. The concluding remarks are made in the last section.

\section{STATE-WISE TRENDS IN MPCE AND CALORIE INTAKE}

The Monthly Per Capita Consumption Expenditure (MPCE) is the total household monthly consumption expenditure adjusted for household size. In unit level data, MPCE is given in paisa and some adjustments have to be made. Table 1 brings out the median income of households that belong to rural areas. The use of median suggests that around 50 per cent of rural households are lower than the average MPCE and close to 50 per cent of rural households are higher than the average MPCE. Thus, the median divides the total households into two equal parts.

In 2004-05, rural states had an average MPCE of Rs.548 which rose to Rs.1349 in 2011-12. Among the states, Kerala Punjab, Haryana, Andhra Pradesh and Gujarat rank high in terms of monthly per capita consumption expenditure. It has also to be noted that the Southern states such as Andhra Pradesh, Tamil Nadu and Kerala have grown more in terms of income than that of the prosperous state Maharashtra. Among the backward states, the states that have made notable progress in terms of MPCE are Rajasthan and West Bengal. A striking pattern emerging from the analysis is that a threefold increase in income could be observed in most of the advanced states, whereas income has nearly doubled in backward states between 2004-05 and 2011-12.

The highest income earning household was located in the state of Tamil Nadu and the lowest one was in Kerala during 2004-05. In 2011-12, Kerala and Andhra Pradesh took over the positions of highest and lowest income earning households.

Table 2 provides these results on median calorie consumption in rural states. The increase in calorie intake in rural areas was marginal as compared to income. During 2004-05 and 2011-12, the highest growth in calorie intake was observed in the states of Andhra Pradesh, Karnataka and Maharashtra. The states such as Punjab, Haryana and Rajasthan shared the top three ranks in terms of the consumption of all macro nutrients. 
Table 1: Summary Statistics of MPCE

\begin{tabular}{|l|c|c|c|c|c|c|}
\hline \multirow{2}{*}{ State } & \multicolumn{3}{|c|}{ 2004-05 } & \multicolumn{3}{c|}{ 2011-12 } \\
\cline { 2 - 7 } & Median & Minimum & Maximum & Median & Minimum & Maximum \\
\hline Andhra Pradesh & 543 & 14 & 31891 & 1537 & 364 & 30522 \\
\hline Gujarat & 593 & 76 & 20748 & 1529 & 410 & 58236 \\
\hline Haryana & 736 & 167 & 32254 & 1742 & 390 & 167462 \\
\hline Karnataka & 483 & 50 & 28926 & 1355 & 500 & 206427 \\
\hline Kerala & 869 & 0 & 81751 & 2217 & 419 & 413310 \\
\hline Maharashtra & 530 & 22 & 13215 & 1471 & 234 & 52361 \\
\hline Punjab & 803 & 212 & 11849 & 1902 & 485 & 39923 \\
\hline Tamil Nadu & 541 & 34 & 102268 & 1549 & 327 & 46301 \\
\hline Assam & 556 & 131 & 2830 & 1176 & 321 & 9784 \\
\hline Bihar & 426 & 146 & 3011 & 1040 & 252 & 12821 \\
\hline Madhya Pradesh & 432 & 19 & 12395 & 1090 & 228 & 36114 \\
\hline Orissa & 373 & 10 & 16082 & 979 & 148 & 16876 \\
\hline Rajasthan & 558 & 47 & 22280 & 1386 & 303 & 68912 \\
\hline Uttar Pradesh & 492 & 74 & 44220 & 980 & 92 & 34519 \\
\hline West Bengal & 530 & 136 & 17650 & 1331 & 398 & 15660 \\
\hline \multicolumn{1}{|c|}{ Total } & $\mathbf{5 4 8}$ & $\mathbf{0}$ & $\mathbf{1 0 2 2 6 8}$ & $\mathbf{1 3 4 9}$ & $\mathbf{9 2}$ & $\mathbf{4 1 3 3 1 0}$ \\
\hline
\end{tabular}

Source: NSS Unit Record Data on Consumer Expenditure

\section{ESTIMATION OF MACRO NUTRIENTS}

For estimating the macro nutrients, the quantity figures of food items of each household given in the NSS unit record data are multiplied by the nutrient contents. This is further divided by household size and by 30 in order to get the daily consumption of nutrients per person. The information on the nutrient content of each food item is sourced from the publications of the National Institute of Nutrition (Gopalan et al, 2000). The number of food items reported in the Nutritive Value of Indian Foods (NVIF) is close to 451 and there was nearly a perfect match of food items in the NVIF and NSS consumer expenditure reports for more than 102 food items. For about 15 items that were listed in the National Sample Survey Data, there was no corresponding match in Gopalan et al., either because these items were cooked, or were less commonly consumed. In these cases, the nutrient content is matched with the closest substitutes.

Instead of relying on a particular calorie cutoff point, the mean RDA has been estimated at the household level after adjusting for age, gender and activity status. To materialize this, the revised RDA for Indians published by the Expert Group of ICMR (2010) is used.

According to the revised RDA, the recommended dietary allowance of calories, protein and fat would be in the order of 2320, 60 and 25 for males who is aged over 14 (Table 3). In the case of females, the age, gender and activityadjusted requirements of nutrients can vary and it is 1900, 55 and 20 respectively. The calorie requirements were the highest in the age group 13-14, irrespective of gender. One of the limitations of our nutritional estimation is associated with the activity status of household members which is reckoned as sedentary for all of them. It is widely believed that the nutrient requirements of an individual vary with age, sex, height, weight, activity pattern, climate, water quality and so on (Himanshu, 2010).

Table 2: Median Intake of Macro Nutrients across the Rural Households

\begin{tabular}{|l|c|c|c|c|c|c|}
\hline \multirow{2}{*}{ State } & \multicolumn{3}{|c|}{ 2004-05 } & \multicolumn{3}{c|}{ 2011-12 } \\
\cline { 2 - 7 } & C & P & F & C & P & F \\
\hline Andhra Pradesh & 1929 & 48 & 24 & 2200 & 54 & 44 \\
\hline Gujarat & 1791 & 53 & 36 & 1978 & 52 & 58 \\
\hline
\end{tabular}




\begin{tabular}{|l|c|c|c|c|c|c|}
\hline \multicolumn{7}{|c|}{ Table 2: Contd., } \\
\hline Haryana & 2188 & 67 & 53 & 2194 & 65 & 59 \\
\hline Karnataka & 1768 & 47 & 27 & 2076 & 52 & 46 \\
\hline Kerala & 2043 & 55 & 41 & 2030 & 56 & 47 \\
\hline Maharashtra & 1837 & 52 & 34 & 2149 & 57 & 54 \\
\hline Punjab & 2247 & 67 & 59 & 2344 & 67 & 65 \\
\hline Tamil Nadu & 1810 & 46 & 21 & 1986 & 50 & 42 \\
\hline Assam & 2061 & 51 & 25 & 2042 & 50 & 28 \\
\hline Bihar & 2095 & 58 & 29 & 2159 & 60 & 36 \\
\hline Madhya Pradesh & 1935 & 58 & 31 & 2134 & 62 & 42 \\
\hline Orissa & 2020 & 47 & 16 & 2152 & 51 & 25 \\
\hline Rajasthan & 2150 & 68 & 47 & 2283 & 68 & 58 \\
\hline Uttar Pradesh & 2167 & 64 & 33 & 2124 & 60 & 40 \\
\hline West Bengal & 2036 & 50 & 26 & 2105 & 52 & 34 \\
\hline \multicolumn{1}{|c|}{ Total } & $\mathbf{2 0 5 3}$ & $\mathbf{5 5}$ & $\mathbf{3 0}$ & $\mathbf{2 1 3 6}$ & $\mathbf{5 6}$ & $\mathbf{4 1}$ \\
\hline
\end{tabular}

Source: As in Table 1

Table 3: Summary of RDA for Indians

\begin{tabular}{|l|l|l|l|l|}
\hline \multicolumn{1}{|c|}{ Group } & \multicolumn{1}{|c|}{ Age } & Calorie & Protein & Fat \\
\hline Infants & Less than 1 & 585 & 10.2 & 19 \\
\hline Children & $1-3$ & 1060 & 16.7 & 27 \\
\hline Children & $4-6$ & 1350 & 20.1 & 25 \\
\hline Children & $7-9$ & 1690 & 29.5 & 30 \\
\hline Children & $10-12$ & 2100 & 40.0 & 35 \\
\hline Male & $13-14$ & 2750 & 54.3 & 45 \\
\hline Female & $13-14$ & 2330 & 51.9 & 40 \\
\hline Male & $15-59$ & 2320 & 60.0 & 25 \\
\hline Female & $15-59$ & 1900 & 55.0 & 20 \\
\hline Male & $60 \&$ above & 2320 & 60.0 & 25 \\
\hline Female & $60 \&$ above & 1900 & 55.0 & 20 \\
\hline
\end{tabular}

Source: ICMR, 2010; Note: RDA is given here for those doing sedentary work.

\section{Concept of Deprivation}

By deprivation we mean relative disadvantage. Townsend (1987) defines deprivation as "a state of observable and demonstrable disadvantage relative to the local community or the wider society or nation to which an individual, family or group belongs". Deprivations come in a variety of forms such as starvation, undernourishment, morbidity, mortality, illiteracy and so on (Sen, 2000). These deprivations are masked by the income distribution statistics. The present study focuses on deprivation with regard to the undernourishment alone.

Broadly speaking, there are two ways by which one can identify the number of households which are deprived. These are (a) absolute deprivation and (b) relative deprivation. According to absolute deprivation, the standard would be fixed as a norm by an expert group. Households which cannot achieve that specified amounts are considered as deprived households.

Relative deprivation is used in an objective sense to depict situations where people lack income, favorable employment conditions or power, than do others. For relative deprivation, the standard is set according to the society or class to which it belongs and households which cannot achieve that standard are called relatively deprived. In other words, relative deprivation is more concerned with the inequality in nutritional intake across the groups. An objective diagnosis of conditions of relative deprivation calls for an objective understanding of feelings of deprivation. 
Any deprivation measurement can be either unidimensional or multidimensional. The unidimensional measures based on FGT indices are more common in the poverty and nutrition literature. The FGT indices are based on the monotonicity and transfer principles; the incidence of undernutrition violates the monotonicity axiom but it is captured by the depth of undernutrition, let alone the transfer principle. Both the axioms are incorporated when the severity of undernutrition is used. The monotonicity axiom looks at the increase in undernutrition as result of lower calorie achievement levels. On the other hand, the transfer axiom proposes that the decrease in undernutrition levels when food is transferred from the richer household to the poorer household (Alkire and Foster, 2011).

The Foster-Greer Thorbeck indices (1984) that measure the incidence, depth and severity of undernutrition are computed here for all macro nutrients. These indices are the most reliable ones when the deprivation is unidimensional in nature. The FGT index can be specified as follows:

$$
\mathrm{FGT}^{\alpha}=(1 / \mathrm{n}) \sum\left[\mathrm{Q}^{\mathrm{R}}-\mathrm{Q}^{\mathrm{E}} / \mathrm{Q}^{\mathrm{R}}\right]^{\alpha}
$$

Where $\mathrm{Q}^{\mathrm{R}}$ is the minimum required calories (RDA), $\mathrm{Q}^{\mathrm{E}}=$ estimated calorie intake of the household and $\mathrm{n}$ is the total number of households. The sigma symbol refers to the summation of all households those consume less than minimum requirement.

When $\alpha=0$, the formula shows the Head Count Index which represents the proportion of households whose calorie consumption fall below the minimum requirement. This simple measure discards the depth of undernourishment. When $\alpha=1$, the Proportionate Gap Index can be calculated. It measures the average distance from the minimum requirement, but it is insensitive to the distribution among the undernourished. When $\alpha=2$, the FGT2 index can be calculated. The index takes into account inequality among the undernourished and shows the severity of undernourishment by assigning greater weights to those households which are far from the minimum required calories. Thus, FGT2 index incorporates the idea 'relative deprivation', as measured by outcome inequality among the deprived households.

\section{RESULTS ON NUTRITIONAL DEPRIVATION}

All-India Estimates: As evident in Table 4, there is a significant prevalence of calorie undernutrition which ranges from 24 to 52 per cent during 2011-12. The prevalence of calorie deprivation has declined by 3 percentage points from 44 per cent to 41 per cent. This was not the case with protein deprivation where protein deprivation witnessed a marginal increase. On the other hand, fat deprivation has declined more precipitously than the calorie deprivation.

The depth of calorie deprivation was up from 10 per cent to 12 per cent during 2004-05 to 2011-12 (Table 5). The trend was somewhat similar in respect of proteins as well. As far as the depth and severity of undernutrition are concerned, one could make an observation that both calorie and protein deprivation is precarious for households that belong to rural areas. Interestingly, fat deprivation has come down by half when all measures of undernutrition are considered.

State-Level Estimates: The state-level estimates exhibits an interesting pattern: the status of Southern and Western states is dubious, given their higher head count ratio of nutrients. Thus, Andhra Pradesh, Kerala, Karnataka, Tamil Nadu, Gujarat and Maharashtra are historically notorious for calorie deprivation and this pattern is consistent with the studies by Sharma (2015), Jha and Gaiha (2003) and Meenakshi and Vishwanathan (2003). The use of calorie thresholds and age-gender adjusted nutritional norms do not produce contrasting results when we look at the case of some leading states, already noted above. These leading states due to better infrastructure, better health care and good sanitation facilities have improved ways of the absorption of nutritional intake. Furthermore, how far recall method has been successful in 
capturing the consumption of home-away cooked meals, processed foods and beverages is doubtful in the case of developed states. Hence, the nutritional deprivation in these states does not matter for the policy-makers.

A comparison of the prevalence, depth and severity of calorie deprivation shows that the states such as Punjab and Rajasthan are nutritionally better off. Only a quarter of households were calorie deprived in these states. The reasons are yet to be explored for the lower calorie deprivation in Rajasthan, despite the poor health status and widespread illiteracy of the state (Sagar, 2010).

More than half of the rural households were undernourished in the states of Gujarat and Tamil Nadu, respectively. Close to 50 per cent of households did so in the states of Kerala and Assam.

The head-count index of protein deprivation ranged from 5 per cent (Rajasthan) to 57 per cent (Orissa) in 2004-05 and from 7 per cent (Rajasthan) to 50 per cent (Assam) for 2011-12. Out of 15 major states, the prevalence of protein deprivation has increased in 8 states. As many as half of the rural households were protein deprived in Tamil Nadu, Assam and Orissa. Another interesting pattern emerges here is that fat deprivation declined more sharply than that of protein deprivation.

When we delve deeper into the state-wise comparison, it can be seen that fat deprivation was stubbornly highest in the states of Orissa (50\%), Assam (44\%) and West Bengal (31\%). In rest of the states, the head-count ratio of fat deprivation gone down by half. This matches with the fact that fat consumption has not ratified any declining trend for rural India as the per capita consumption of edible oils steadily improved (Deaton and Dreze, 2009; Gupta, 2012).

Table 4: State-Wise Head Count Ratios of Macro Nutrients

\begin{tabular}{|l|c|c|c|c|c|c|}
\hline \multirow{2}{*}{ State } & \multicolumn{3}{|c|}{$\mathbf{2 0 0 4 - 0 5}$} & \multicolumn{3}{c|}{$\mathbf{2 0 1 1 - 1 2}$} \\
\cline { 2 - 7 } \multicolumn{1}{|c|}{ C } & $\mathbf{P}$ & $\mathbf{F}$ & $\mathbf{C}$ & $\mathbf{P}$ & $\mathbf{F}$ \\
\hline Andhra Pradesh & 51.34 & 51.31 & 51.87 & 44.16 & 45.86 & 17.52 \\
\hline Gujarat & 64.96 & 37.50 & 24.09 & 52.10 & 48.19 & 10.34 \\
\hline Haryana & 33.10 & 11.61 & 6.96 & 32.16 & 12.71 & 2.39 \\
\hline Karnataka & 56.49 & 53.30 & 46.01 & 47.46 & 48.24 & 17.92 \\
\hline Kerala & 47.65 & 43.74 & 23.95 & 49.73 & 43.20 & 15.25 \\
\hline Maharashtra & 57.83 & 45.50 & 31.83 & 45.86 & 42.16 & 12.80 \\
\hline Punjab & 31.28 & 10.32 & 2.42 & 24.23 & 11.47 & 0.77 \\
\hline Tamil Nadu & 55.71 & 55.69 & 55.76 & 51.58 & 50.47 & 22.24 \\
\hline Assam & 43.04 & 44.12 & 52.36 & 49.31 & 50.65 & 43.94 \\
\hline Bihar & 34.34 & 14.77 & 39.44 & 33.54 & 17.39 & 19.29 \\
\hline Madhya Pradesh & 49.87 & 20.06 & 33.27 & 47.50 & 37.29 & 24.79 \\
\hline Orissa & 47.71 & 57.17 & 75.44 & 45.81 & 50.18 & 50.08 \\
\hline Rajasthan & 30.44 & 4.94 & 6.92 & 26.21 & 7.29 & 3.80 \\
\hline Uttar Pradesh & 30.03 & 10.80 & 31.16 & 34.57 & 16.94 & 15.72 \\
\hline West Bengal & 45.37 & 46.45 & 46.63 & 45.80 & 46.64 & 30.75 \\
\hline \multicolumn{1}{|c|}{ Total } & $\mathbf{4 3 . 8 9}$ & $\mathbf{3 4 . 8 0}$ & $\mathbf{4 0 . 4 7}$ & $\mathbf{4 1 . 2 4}$ & $\mathbf{3 5 . 7 9}$ & $\mathbf{2 3 . 9 4}$ \\
\hline Source: Estimal
\end{tabular}

Source: Estimated from NSS Unit Record Data

Table 5: Depth of Deprivation of Macro Nutrients

\begin{tabular}{|l|c|c|c|c|c|c|}
\hline \multirow{2}{*}{ State } & \multicolumn{3}{|c|}{$\mathbf{2 0 0 4 - 0 5}$} & \multicolumn{3}{c|}{$\mathbf{2 0 1 1 - 1 2}$} \\
\cline { 2 - 7 } & C & P & F & C & P & F \\
\hline Andhra Pradesh & 19.45 & 19.37 & 24.18 & 14.75 & 15.77 & 5.18 \\
\hline Gujarat & 13.26 & 6.65 & 7.07 & 18.29 & 16.50 & 3.08 \\
\hline Haryana & 4.95 & 1.57 & 1.34 & 3.99 & 1.42 & 0.30 \\
\hline Karnataka & 22.61 & 20.97 & 19.44 & 17.19 & 17.68 & 5.81 \\
\hline
\end{tabular}




\begin{tabular}{|l|c|c|c|c|c|c|}
\hline \multicolumn{7}{|c|}{ Table 5: Contd., } \\
\hline Kerala & 16.45 & 15.53 & 8.33 & 16.15 & 13.82 & 4.60 \\
\hline Maharashtra & 16.84 & 13.14 & 11.31 & 15.70 & 14.41 & 4.12 \\
\hline Punjab & 4.14 & 1.19 & 0.38 & 2.66 & 1.20 & 0.08 \\
\hline Tamil Nadu & 21.59 & 21.86 & 27.87 & 17.62 & 17.73 & 6.79 \\
\hline Assam & 6.06 & 7.07 & 15.36 & 14.55 & 15.26 & 14.35 \\
\hline Bihar & 4.63 & 1.80 & 10.61 & 4.49 & 2.23 & 4.17 \\
\hline Madhya Pradesh & 8.13 & 2.78 & 8.37 & 16.15 & 11.77 & 7.33 \\
\hline Orissa & 8.15 & 11.79 & 32.76 & 15.37 & 17.27 & 19.30 \\
\hline Rajasthan & 3.70 & 0.67 & 1.22 & 3.20 & 0.71 & 0.80 \\
\hline Uttar Pradesh & 4.43 & 1.59 & 8.06 & 4.59 & 2.14 & 3.21 \\
\hline West Bengal & 6.82 & 7.62 & 13.68 & 15.18 & 15.74 & 9.97 \\
\hline \multicolumn{1}{|c|}{ Total } & $\mathbf{9 . 6 2}$ & $\mathbf{8 . 3 5}$ & $\mathbf{1 5 . 0 0}$ & $\mathbf{1 1 . 6 7}$ & $\mathbf{1 0 . 9 1}$ & $\mathbf{8 . 2 4}$ \\
\hline
\end{tabular}

Source: Estimated from NSS Unit Record Data

At all-India level, the depth of calorie deprivation marginally increased from $10 \%$ to $12 \%$. This marginal improvement might take after the increase reported in six states. It can also be inferred that the depth of calorie deprivation was long-lasting in backward states, except for Bihar and Rajasthan.

The protein gap has substantially gone down in most of the advanced states. The protein gap has increased in the states of Assam, Orissa, West Bengal and Madhya Pradesh and it is worrisome. The depth of fat deprivation declined in all states, but the decline was not satisfactory in backward states.

Table 6: Severity of Deprivation of Macro Nutrients

\begin{tabular}{|c|c|c|c|c|c|c|}
\hline \multirow{2}{*}{ State } & \multicolumn{3}{|c|}{ 2004-05 } & \multicolumn{3}{|c|}{ 2011-12 } \\
\hline & $\mathbf{C}$ & $\mathbf{P}$ & $\mathbf{F}$ & $\mathrm{C}$ & $\mathbf{P}$ & $\mathbf{F}$ \\
\hline Andhra Pradesh & 10.08 & 10.13 & 14.65 & 6.89 & 7.53 & 2.32 \\
\hline Gujarat & 4.26 & 2.29 & 3.40 & 8.86 & 7.91 & 1.38 \\
\hline Haryana & 1.17 & 0.39 & 0.41 & 0.78 & 0.25 & 0.07 \\
\hline Karnataka & 12.08 & 11.16 & 11.01 & 8.70 & 9.00 & 2.81 \\
\hline Kerala & 8.02 & 7.74 & 4.20 & 7.44 & 6.45 & 2.15 \\
\hline Maharashtra & 7.44 & 5.84 & 5.67 & 7.60 & 7.01 & 2.01 \\
\hline Punjab & 0.91 & 0.29 & 0.12 & 0.49 & 0.23 & 0.01 \\
\hline Tamil Nadu & 11.28 & 11.60 & 17.82 & 8.46 & 8.63 & 3.09 \\
\hline Assam & 1.40 & 1.72 & 6.29 & 6.11 & 6.49 & 6.50 \\
\hline Bihar & 1.01 & 0.41 & 3.99 & 0.97 & 0.46 & 1.36 \\
\hline Madhya Pradesh & 2.04 & 0.68 & 3.05 & 7.63 & 5.41 & 3.18 \\
\hline Orissa & 2.31 & 3.55 & 17.62 & 7.22 & 8.26 & 9.99 \\
\hline Rajasthan & 0.79 & 0.22 & 0.37 & 0.64 & 0.13 & 0.25 \\
\hline Uttar Pradesh & 1.13 & 0.47 & 2.94 & 1.00 & 0.49 & 1.02 \\
\hline West Bengal & 1.64 & 1.96 & 5.54 & 7.08 & 7.46 & 4.69 \\
\hline Total & 3.74 & 3.43 & 7.71 & 5.14 & 4.99 & 4.08 \\
\hline
\end{tabular}

Source: Estimated from NSS Unit Record Data

A glance at Table 6 shows that the severity of calorie deficiency has substantially reduced in most of the advanced states. The experience of some states such as Gujarat, Assam, Madhya Pradesh, Orissa and West Bengal shows that the severity of calorie and protein deprivation has increased by six percentage points in between the periods under consideration. All states have confirmed a decline with respect to the severity of fat deprivation. Nevertheless, fat deprivation was highest in the states of Orissa (10\%), Assam (7\%) and West Bengal (5\%). 


\section{Factors Influencing the Nutritional Deprivation}

The previous studies have estimated the calorie deprivation of rural India, by accommodating a set of norms such as 1800, 2100, 2200, 2400 and 2700 (Meenakshi and Viswanathan, 2003; Suryanarayana and Silva, 2008; Gupta and Mishra, 2013; Mishra, 2010). These studies are largely misleading owing to the inclusion of arbitrary norms. In an exceptional study by Sharma (2015) the Recommended Dietary Allowance has been calculated after adjusting for age, gender and occupation of the households. As the RDA requirements of different households is different, the present study also offers an error-free approach in this regard by working out the age, gender and occupation adjusted calorie requirements and finally measures the calorie deprivation if the Recommended Dietary Allowance (RDA) surpasses the calorie intake of the household. The methodological difference of the work lies in the inclusion of calories (proteins/fats) derived from those food items such as pan, ganga, toddy, country/foreign liquor, beer and other intoxicants. Our presentiment is that the exclusion of these unhealthy food items is likely to intensify the nutrient deprivation in rural India.

The binary logistic regression method has been used to study the income-calorie nexus. The $\mathrm{CD}_{\mathrm{i}}$ is the dependent variable and monthly per capita consumption expenditure, household size and land ownership are the independent variables of interest. The $\mathrm{CD}_{\mathrm{i}}$ is equal to one if the household is calorie deprived and otherwise zero is recorded.

To get an insight into the probability of being calorie deprived across socio-economic and demographic groups, a logit model has been fitted as:

$$
\ln \left(\pi_{\mathrm{i}} / 1-\pi_{\mathrm{i}}\right)=\alpha+\beta \mathrm{X}_{\mathrm{i}}+\varepsilon_{\mathrm{i}}
$$

Where $(\pi / 1-\pi)$ is called the odds ratio. The estimated probability $(\pi)$ is obtained as follows:

$$
\pi=1 / 1+\mathrm{e}^{-\mathrm{x}}
$$

Where $\mathrm{x}$ is the predictor variable and $\mathrm{e}$ is the base of natural logarithm with a value of 2.7183 .

In case more than one explanatory variable is included, then the model becomes:

$$
\ln \left(\pi_{\mathrm{i}} / 1-\pi_{\mathrm{i}}\right)=\beta_{1}+\beta_{2} \mathrm{X}_{2 \mathrm{i}}+\beta_{3} \mathrm{X}_{3 \mathrm{i}}+---\cdot----+\beta_{\mathrm{k}} \mathrm{X}_{\mathrm{ki}}+\varepsilon_{\mathrm{i}}
$$

\section{Rationale behind the Selection of Variables}

\section{Income}

The impact of monthly per capita consumption expenditure, a proxy for income, is well-documented in literature. Income determines access to food and non-food items and enables an individual to live longer and healthy. This means that access to education and health services are dictated by income and its sources. There is an expected inverse relationship between income and calorie deficiency in which the latter marks a decline with the increment in income. However, there are chances that when income increases, households may not apportion all of their income on calories. As a result, the impact of income on calories would be less influential.

As given in Table 7, the logit model shows that rich households are 0.65 times less likely to be undernourished than their counterparts in poor households. Similar picture holds for those households that falls prey to protein deprivation. 


\section{Land Ownership}

Land ownership, a measure of household wealth, exerts a negative influence on calorie deprivation. The coefficient for land ownership is significant, but negative. It implies that when a household has access to land, its calorie deprivation decreases. This goes in line with the argument that self-production of cereals contributes to an increment in calorie intake (Basu and Basole, 2012).

However, land ownership does not significantly contribute to the protein deprivation which indicates that the production base of the rural households is not diversified to date (Table 8).

\section{Household Type}

The rural households are broken down into six categories: self-employed in agriculture, self-employed in nonagriculture, salary earner, causal labour in agriculture, causal labour in non-agriculture, and others. Not surprisingly, causal labour in agriculture and households which are self-employed in non-agriculture are the most calorie and protein deprived households.

\section{Access to PDS}

The possession of a ration card is the basic criterion that determines access to the PDS services. The rural households that have been excluded from the PDS owing to the lack of ration card were about 15 per cent in 2011-12. The share was much higher in Orissa and Assam, with 33 per cent and 18 per cent, respectively. It is hoped that the inclusion of the variable - no ration card households may point to the errors in tracing the true beneficiaries of targeted public distribution system. Contrary to the expectation, our results endorse that households having zero ration cards are 0.85 (0.80) times less likely to be calorie (protein) deprived.

\section{Religion and Caste Type}

Hindu, Christian and Muslim are the predominant religions in the country. Other religions such as Buddhists, Sikhs, Jains, and Zoroastrians are clubbed into the category of 'others'. Among the religious groups, Christians face more calorie deprivation than other all other religious groups. Hindus comes next in calorie deprivation, followed by Muslim households. The protein deficiency among Christians is more precarious than calorie deficiency.

Across the social groups, ST and OBC households were the most calorie deprived groups. The SC households were found to be the least calorie deprived category, but calorie deprivation was not significant at all. Similar trend can be observed in protein deprivation as well.

\section{Dependency Burden}

The number of persons below 15 and above 60 adequately captures the dependency burden confronted by rural households. Our results show that old persons are on par with children in terms of calorie deprivation. Overall the dependent population makes a significant contribution towards calorie deficiency. Coming to the case of protein deprivation, children seem to be well-nourished. The old population needs less protein when they step into higher age brackets.

Table 7: Logistic Regression Analysis of the Probability of Being Calorie Deprived ( $N=59693)$

\begin{tabular}{|c|c|c|}
\hline Variables & Coefficient & Odds Ratio \\
\hline Constant & $2.23 *_{* *}$ & 8.005 \\
\hline
\end{tabular}




\begin{tabular}{|c|c|c|}
\hline \multicolumn{3}{|c|}{ Table 7: Contd., } \\
\hline $\begin{array}{l}\text { MPCE } \\
\text { Natural Logarithm of MPCE }\end{array}$ & $-0.426 * * *$ & 0.653 \\
\hline $\begin{array}{l}\text { No of persons Below } 15 \\
\text { No of persons Below } 60\end{array}$ & $\begin{array}{c}0.038 * * \\
0.150 * * *\end{array}$ & $\begin{array}{l}1.038 \\
1.162 \\
\end{array}$ \\
\hline $\begin{array}{l}\text { Land Ownership } \\
\text { Have Some Land } \\
\text { (REF = Landless) }\end{array}$ & $-0.319 * * *$ & 1.376 \\
\hline $\begin{array}{l}\text { No Ration Card } \\
\text { (REF = Have Ration Card) }\end{array}$ & $-1.166_{* *}$ & 0.847 \\
\hline $\begin{array}{l}\text { Social Group } \\
\text { ST } \\
\text { SC } \\
\text { OBC } \\
\text { (REF = Others) }\end{array}$ & $\begin{array}{c}0.355^{* * *} * \\
0.077^{\mathrm{NS}} \\
0.239^{* * *}\end{array}$ & $\begin{array}{l}1.426 \\
1.080 \\
1.270\end{array}$ \\
\hline $\begin{array}{l}\text { Religion } \\
\text { Hindu } \\
\text { Muslim } \\
\text { Christian } \\
\text { (REF = Others) }\end{array}$ & $\begin{array}{l}0.538 * * * \\
0.506 * * * \\
1.325 * * *\end{array}$ & $\begin{array}{l}1.713 \\
1.659 \\
3.762\end{array}$ \\
\hline $\begin{array}{l}\text { Household Type } \\
\text { Self-employed in Agriculture } \\
\text { Self-employed in Non-agriculture } \\
\text { Regular wage/salary earning } \\
\text { Causal labour in Agriculture } \\
\text { Causal Labour in Non-agriculture } \\
\text { (REF = Others) }\end{array}$ & $\begin{array}{l}0.429 * * * \\
0.619 * * * \\
0.536 * * * \\
0.692 * * * \\
0.544 * * *\end{array}$ & $\begin{array}{l}1.537 \\
1.856 \\
1.709 \\
1.998 \\
1.723\end{array}$ \\
\hline
\end{tabular}

Source: Computed from NSS $68^{\text {th }}$ round unit-record data McFadden Pseudo $\mathrm{R}^{2}$ : 0.028; Model

Chi-square: $330.26^{* * *}$; Log likelihood ratio: -5715.908 Note: Odds ratios less than 1 correspond to decreases and odd ratios more than 1 correspond to increases in odds. Odds ratios close to 1 indicate that unit changes in that independent variable do not affect the dependent variable. ${ }^{*}$ Significant at $10 \% ;{ }^{* *}$ Significant at $5 \% ;{ }^{* * *}$ Significant at $1 \%$

Table 8: Logistic Regression Analysis of the Probability of Being Protein Deprived ( $=$ 59693)

\begin{tabular}{|l|c|c|}
\hline \multicolumn{1}{|c|}{ Variables } & Coefficient & Odds Ratio \\
\hline Constant & $1.288^{* * * *}$ & 3.502 \\
\hline MPCE & & \\
Natural Logarithm of MPCE & $-0.331^{* * *}$ & 0.718 \\
\hline No of persons Below 15 & $-0.097^{* * *}$ & 0.908 \\
No of persons Below 60 & $0.066^{\mathrm{NS}}$ & 1.068 \\
\hline Land Ownership & & \\
Have Some Land & $-0.192^{\mathrm{NS}}$ & 1.212 \\
(REF = Landless) & & \\
\hline No Ration Card & $-0.218^{* * *}$ & 0.804 \\
(REF = Have Ration Card) & & \\
\hline Social Group & & \\
ST & $0.559^{* * *}$ & 1.748 \\
SC & $-0.011^{\mathrm{NS}}$ & 0.989 \\
OBC & $0.212^{* * *}$ & 1.237 \\
(REF = Others) & & \\
\hline Religion & & 2.278 \\
Hindu & $0.823^{* * *}$ & 2.271 \\
Muslim & $0.820^{* * *}$ & 5.068 \\
Christian & $1.623^{* * *}$ & \\
(REF = Others) & & \\
\hline
\end{tabular}




\begin{tabular}{|l|l|l|}
\hline Household Type & \\
Self-employed in Agriculture & $0.433^{* * *}$ & 1.542 \\
Self-employed in Non- & $0.625^{* * *}$ & 1.867 \\
agriculture & $0.616^{* * *}$ & 1.852 \\
Regular wage/salary earning & $0.572^{* * *}$ & 1.771 \\
Causal labour in Agriculture & $0.359^{* * *}$ & 1.431 \\
Causal Labour in Non- & & \\
agriculture & & \\
(REF = Others) & & \\
\hline
\end{tabular}

Source: Computed from NSS $68^{\text {th }}$ round unit-record data McFadden Pseudo R ${ }^{2}$ : 0.032; Model Chisquare: $385.699^{* * *}$; Log likelihood ratio: -5814.413 Note: Odds ratios less than 1 correspond to decreases and odd ratios more than 1 correspond to increases in odds. Odds ratios close to 1 indicate that unit changes in that independent variable do not affect the dependent variable. "Significant at $10 \% ;{ }^{* *}$ Significant at $5 \% ;{ }^{* * *}$ Significant at $1 \%$

\section{CONCLUSIONS}

The aim of the paper was to quantify the proportion of undernourished households in rural India without relying on any particular calorie cutoff point. To do so, average RDA has been estimated at the household level, after adjusting for age and gender distribution of the sedentary household members. In order to pin down the nutritional deprivation, an attempt has been made to estimate the nutrients consumption derived from the quantity figures laid out in NSS unit record data and the nutrient contents drawn from the Nutritive Value of Indian Foods. The two NSS rounds that pertain to the years 2004-05 and 2011-12 are used here.

The depth of calorie deprivation shows that calorie intake has improved a lot, while the opposite results hold for proteins. The depth and severity of calorie deprivation have marginally increased over the two NSS periods. In terms of head count ratio, protein deficiency seems to be lesser than calorie deficiency, but as for the depth and severity, protein deficiency is close to calorie deprivation. Fat deprivation in rural India marks a significant reduction and it is neither severe nor persistent. The decline in fat deprivation is plausible, given the steady increase in the consumption of edible oils.

An investigation of the determinants of calorie deprivation leads us to the finding that poor households, ST and OBC households, causal labour in agriculture, self-employed in non-agriculture and Christians are the most calorie deprived groups. Both the old and child population contributes significantly towards calorie deprivation, however, protein deficiency is not severe amongst these vulnerable groups. Households having some land will amount significantly to the calorie deficiency which is unlikely the case with protein deficiency.

Among the backward states, higher incidence of nutritional deprivation persists among Assam, Madhya Pradesh, Orissa and West Bengal. The legacy of higher calorie deprivation in leading states is not a cause of worry. Lower the nutritional intake, higher will be the absorption level in Southern and Western states due to their improved ways of living. This is further reflected in the lower incidence of stunting and underweight among children in these states (Mishra and Mishra, 2009).

\section{REFERENCES}

1. Ahluwalia, M.S. (2011), "Prospects and Policy Challenges in the Twelfth Plan", Economic and Political Weekly, Vol.46, No.21, pp. 88-105.

2. Alkire, Sabina and James Foster (2011), "Understandings and misunderstandings of multidimensional poverty measurement", Journal of Economic Inequality, Vol.9, No.2, pp.289-314. 
3. Audu, V.I. and Goodness C.A. (2014), "The effects of improved maize technology on household welfare in Buruku, Benue State, Nigeria”, Cogent Economics and Finance, Vol.2, pp.1-10.

4. Basu, D. and Debarshi D. (2014), "Poverty-Hunger Divergence in India', Economic and Political Weekly, Vol.49, No.2, pp.22-24.

5. Bhagowalia, Priya, Derek Heady and Suneetha Kadiyala (2012), “Agriculture, Income, and Nutrition Linkages in India: Insights from a Nationally Representative Survey”, IFPRI Discussion Paper 01195, IFPRI.

6. Foster, James, Joel Greer and Erik Thorbecke (1984), “A Class of Decomposable Poverty Measures”, Econometrica, Vol.52, No.3, pp.761-766.

7. Gaiha, Raghav, Raghbendra Jha and Vani S. Kulkarni (2010), "Demand for Nutrients in India, 1993-2004”, ASARC Working Paper 2010/16, Canberra.

8. Gopalan, C., B.V. Rama Sastri and S.C. Balasubramanian (1989), Nutritive Value of Indian Foods, National Institute of Nutrition, Hyderabad.

9. Gupta, Abha and Deepak K. Mishra (2013), "Poverty and calorie deprivation across social-economic groups in rural India", Journal of Regional Development and Planning', Vol.2, No.1, pp.15-33.

10. Gupta, Dipankar (2015), “The Importance of Being 'Rurban': Tracking Changes in a Traditional Setting”, Economic and Political Weekly, Vol.50, No.24, pp.37-43.

11. Gupta, Shalini (2012), "Food Expenditure and Intake in the NSS $66^{\text {th }}$ Round”, Economic and Political Weekly, Vol.47, No.2, pp. 23-26.

12. Himanshu (2010), “Towards New Poverty Lines for India”, Economic and Political Weekly, Vol.45, No.1, pp. 38-48.

13. Jha, Raghbendra and Raghav Gaiha (2003), "Determinants of Undernutrition in Rural India”, Draft, Australian National University, Canberra.

14. Kaicker, N. and R. Gaiha (2013), "Calorie thresholds and undernutrition in India”, Journal of Policy Modelling, Vol.35, No.2, pp.271-288

15. Khan, Amir Ullah and Harsh Vivek (2007), States of the Indian Economy: Towards a Larger Constituency for Second Generation Economic Reforms, Sage Publications, New Delhi.

16. Kumar, Anjani, Sant Kumar, Dhiraj K Singh and Shivjee (2011), "Rural Employment Diversification in India: Trends, Determinants and Implications on Poverty”, Agricultural Economics Research Review, Vol.24, pp.361-372.

17. Lanjouw, Peter and Abusaleh Shariff (2004), "Rural Non-Farm Employment in India: Access, Incomes and Poverty Impact", Economic and Political Weekly, Vol.39, No.40, pp.4429-4446.

18. Meenakshi, J.V., Ranjan Ray and Souvik Gupta (2000), "Estimates of Poverty for SC, ST and Female-Headed Households", Economic and Political Weekly, Vol.35, No.31, pp.2748-2754.

19. Meenakshi, J.V. and Brinda Vishwanathan (2003), "Calorie Deprivation in Rural India: 1983-1999/2000”, Economic and Political Weekly, Vol.38, No.4, pp.369-375.

20. Mishra, Rudra Narayan (2010), "Undernutrition in India: Dimensions and Correlates", Unpublished PhD Thesis, Jawaharlal Nehru University, New Delhi.

21. Mishra, Udaya S. and Rudra Narayan Mishra (2009), "On comparison of nutritional deprivation: an illustration using Foster Greer Thorbecke criterion”, Applied Economics Letters, Vol.16, No.10, pp.1021-1024. 
22. Rao, Veena (2016), "Undernutrition in India: A Case of public policy inertia”, in Sonalde Desai, Lawrence Haddad, Deepta Chopra and Amit Thorat (eds.): Undernutrition and Public Policy in India: Investing in the future, Routledge Publication, New York.

23. Sagar, Vidya (2010), “Economic Growth - Human Development Interface” in Shovan Ray (ed.): Backwaters of Development: Six Deprived States of India, Oxford University Press, New Delhi.

24. Sen, Amartya (2000), Development As Freedom, Oxford University Press, New Delhi.

25. Sharma, Rekha (2015), Quantifying Under-nutrition in Rural India, Academic Foundation, New Delhi.

26. Suryanarayana, M.H. and D. Silva (2008), "Poverty and Food Security in India: A Disaggregated Regional Profile", WP No.005, IGIDR, Mumbai.

27. Virmani, Arvind (2008), "Growth and Poverty: Policy Implications for Lagging States", Economic and Political Weekly, Vol.43, No.2, pp.54-62. 
